\title{
Implications of Transactive Memory Systems (TMS) for higher education
}

\author{
Implicaciones del Sistema de memoria transactive para la Educación Superior
}

GARCÍA-CHITIVA, María del Pilar ${ }^{1}$

\begin{abstract}
The demands of today's society require professionals capable of teamwork, who know how to work collaboratively. The so-called "transactive memory system" (TMS) allows understanding the cognitive functioning of individuals when they work in a team. Through a bibliometric analysis of 322 published articles indexed in the Scopus database between 1998 and 2018, we reveal the implications of TMS for higher education institutions. Our results showed the scarce study of the subject in the area of Education despite its potential relevance for higher education. We conclude this article by arguing the implications that TMS supposes for the way in which we normally approach the teaching-learning processes in higher education environments.

Key words: transactive memory system; higher education; collaborative learning; teaching-learning practices

Resumen

Las exigencias de la sociedad actual requieren de profesionales capaces de trabajar en equipo, que sepan trabajar de forma colaborativa. El Ilamado "sistema de memoria transactiva" (TMS) permite comprender el funcionamiento cognitivo de los individuos cuando trabajan en equipo. A través de un análisis bibliométrico de 322 artículos publicados indexados en la base de datos Scopus entre 1998 y 2018, revelamos las implicaciones de TMS para las instituciones de educación superior. Nuestros resultados evidenciaron el escaso estudio de la asignatura en el área de Educación a pesar de su potencial relevancia para la educación superior. Concluimos este artículo argumentando las implicaciones que supone la TMS para la forma en que normalmente abordamos los procesos de enseñanza-aprendizaje en entornos de educación superior.

Palabras clave: Sistema de memoria transactiva; educación más alta; aprendizaje colaborativo; prácticas de enseñanza-aprendizaje
\end{abstract}

\section{Introducción}

The ability to work efficiently, productively and innovatively, in collaboration with others, is an imperative need of today's society (Miller and Hadwin 2015). Higher education plays a crucial role in satisfying such a need because this ability can be taught in educational contexts. Collaboration involves the work that two or more people develop together to achieve common goals (Jhonson et al., +1994 ) with effectively, respectfully and flexible efforts (linuma et al. 2016).

\footnotetext{
${ }^{1}$ Doctoranda en Educación. Doctorado Interinstitucional en Educación -DIE . Universidad. Pedagógica Nacional. mgarcia@pedagogica.edu.co Este artículo hace parte de la tesis doctoral de la autora.
} 
A theoretical approach linked to collaboration is known as the Transactive Memory System (TMS), which allows understanding how information is processed jointly when two or more people collaborate. In other words, TMS refers to how the knowledge of the members of the group is complemented through a shared consciousness about who knows what (Hollingshead et al. 2012). This who-knows-what principle assumes that the members of a group have split the cognitive load for processing information in group mates, integrating different domains of knowledge during the execution of a task (Liang et al. 1995; Hollingshead 2001). A critical factor in the development of TMS is the so-called "cognitive interdependence". As in collaborative learning, interdependence in the TMS occurs when the members of a group know what their experience is and that of their colleagues and understand that they depend on their combination to perform the task satisfactorily. The relationship between TMS and collaborative learning in higher education settings seems to be relevant to understand the functioning of a group when their members need to code, store, and retrieve information in the execution of a task for educative purposes. Nonetheless, as we are not aware of previous studies that have tackled this topic, this work aims to argue the implications of TMS for higher education settings.

The organization of this article is as follows. In the next section, we present a brief review of the theoretical foundations of TMS, then we introduce our methodological approach before the description of our findings. Finally, we conclude by arguing the implications that TMS supposes to the way we normally tackle teachinglearning processes in settings of higher education.

\subsection{Transactive Memory System}

TMS was developed in the realm of social psychology with the paper titled "Cognitive interdependence in close relationships" (Wegner et al., (1985). In that paper the term "Transactive Memory System" was coined to explain how cognitive processes work in groups or dyads with people of remarkable cognitive differences; that is, how knowledge enters into a dyad or group that works together, how they organize this knowledge and how they make it available for later use. This approach diverges from the classical theory of "group mind" that posited the idea that cognitive processes rely on the cognitive similarities that existed between individuals (Wegner et al., $(1985,254)$. TMS, then, is a cognitive property of the group. It results from the interaction between individuals who learn what is the area of expertise of their peers when they have to face problems that deserve the exchange of knowledge and skills for their solution (Wegner 1987).

According to Wegner et al., (1985), TMS possesses two essential components. On the one hand, the first component is an organized knowledge that remains in the individual memory of each member of the group. On the other hand, the second component covers a set of transactive processes (interactions, exchange of ideas, dialogues, etc.) that occur within the group. To better understand this aspect, let's think about Daniel, John, and Peter who are part of the same group. The information that each of them has on a topic has been stored, encoded and recovered in a different way when they have worked alone; however, when they work together to achieve a common goal, the information can be recovered from the memory of the other, when one of them does not remember it, through interpersonal interaction and communication. The interdependence in this way plays an essential role in the configuration of TMS, that can be deemed as two or more minds working together as one (Moreland et al. 1996).

The empirical evidence of TMS is well-known. For example, Hollingshead (2001) showed the existence of statistically significant differences of two groups when individuals were more aware of their cognitive interdependence compared to when they were not so aware of it. Thus, the previous collaborative experience of the members of a group plays an essential factor in the development of transactional memory. Moreland et al., (1996) studied the effect on the performance of ninety couples who were trained under two different conditions for a task consisting of assembling a radio. While half of the couples received training with their 
partner, the others were trained separately. The results showed that there were essential differences in the memory of the steps to follow to assemble the radio. The groups whose members trained in teams remembered more precisely the steps to develop the task and had fewer errors in doing so, compared to the groups made up of individually trained members.

In another study, Brandon \& Hollingshead (2004) proposed a model that included the representation of the task to understand the development of the transactional memory system. According to their model, the TMS that originates in a collaborating group can vary in terms of 1) accuracy (i.e., the accuracy of the perceptions of group members about the expertise of others to solve tasks), 2) sharing (the degree to which members have a shared representation of the transactional memory system) and 3) validation (the degree to which group members participate in the transactional memory system). When the optimal states of precision, sharing and validation take place in a group, it is affirmed that there is "convergence" of their transactional memory, which leads to an increase in the performance of group tasks. Later, Peltokorpi (2008) examined 28 studies in which he identified three levels of TMS analysis: dyads, groups and work teams. According to Peltokorpi (2008), by that time, the state of theoretical research on the subject presented the following gaps: 1) the role of face-to-face communication in the conformation and maintenance of transactional memory systems, 2) the influence of the cognitive diversity present in the groups on the TMS, particularly the contribution of each individual, 3) the incidence of the context of the task on the emergence of the TMS and 4) the understanding of the influence of the differences in the interactions between couples and groups.

In a subsequent review, Ren and Argote (2011) analyzed 76 studies, of which 18 were conceptual or review articles, 25 were documents that showed results of experiments, 31 corresponded to field studies and two documented simulations. With this review, the authors generated a framework of integrative analysis distributed in three sections: 1) the theoretical background of the study on transactive memory at different levels (inputs of group composition, attributes of group members, contextual or organizational inputs), 2) the moderating factors between the relationship of the systems of transactional memory and the results in the performance of the task (group measure, type of task, change in the memberships when performing the task) and 3) the consequences derived, or implications of the transactional memory in the group (team learning, creativity, member satisfaction). The conclusions called attention to three fundamental aspects to be considered in future research: 1) pay greater attention to the inputs of the composition of the groups (diversity-attributes of the members of the groups) and the effects of the organizational contexts in the development of TMS, 2) to explore the use of technologies and guided guidance for group management in order to help the team to function effectively and 3 ) to focus on other areas where teamwork is required, particularly in the area of organizations.

\section{Methodology}

We followed a three-step computer-assisted bibliographic approach (Aria and Cuccurullo 2017) that allowed us to analyze a representative sample of published papers indexed in the Scopus database between 1998 and 2018. In the first step, we retrieved the bibliographic data of all the manuscripts with the term "Transactive Memory System" in the title, the abstract or the keywords, by employing the following search query string in Scopus TITLEABS-KEY ("Transactive Memory System"). The resulting sample of 322 papers was downloaded in bibtex format from Scopus in January 2019 and processed in the R system (R Core Team 2019) with the aid of the "bibliometrix" package (Aria and Cuccurullo 2017). These data are available in the following repository https://data.mendeley.com/datasets/fpgj7vxfsn/1

A preliminary analysis revealed that the total number of published papers of TMS between 1998 and 2008 was lower $(n=61)$ than those published since $2009(n=261)$. In order to understand this difference, our second step consisted of conducting a thorough examination of the resulting 245 published papers between 2008 and 2018. 
In such a review, we analyzed the distribution of articles according to the disciplines of knowledge of their publishing journals. We also obtained the list of most cited works to reveal its authors as well as their most significant contributions to the research on TMS.

In our third step, we employed a network approach (Cherven 2015) to create two types of data frames. The first one is a cited reference data frame and the second one is a keyword data frame. Both of them have relevant data for a cited reference network and a keyword co-occurrence network, respectively. We generated these data frames with the aid of the "bibliometrix" R package (Aria and Cuccurullo 2017), and we used them as inputs for depicting a cited reference network and keyword co-occurrence network with Gephi (Cherven 2015). In the cited reference network, we identified which work (represented as a point or node) was cited by another work (also represented as a point or node), through a straight line that connects them accordingly. In the keyword cooccurrence network each keyword present in each published article is represented as a point or node that is connected with a straight line with other keyword if they both appear together in at least one single article. Put it differently, this keyword co-occurrence network refers to an above-chance frequency of occurrence of two terms or keywords alongside each other from the text corpus of the 245 articles downloaded from Scopus. According to Kroeger (2005), co-occurrence in this linguistic sense can be interpreted as an indicator of the semantic proximity of a term with any other term. In our case, the semantic proximity that TMS has with other terms that are commonly related to education, teaching, and learning we calculated graph statistics that convey this meaning (Cherven 2015). In particular, we estimated the "degree centrality" (i.e., the number of other nodes linked to a specific node), "eccentricity" (i.e., the distance of a single point in the graph to its most distant point) and "closeness centrality" (i.e., the proximity of a selected node to all other nodes within the graph). The calculation of these metrics was implemented in Gephi (Cherven 2015).

Finally, by applying content analysis to these studies we identified those papers that investigated TMS in higher education contexts, and we found that only six manuscripts out of the 245 original articles showed empirical results of TMS with university students. The implications of TMS for higher education were extracted from this selected group of papers. For the sake of completeness and organization, we structured the results in three subsections: "preliminary analysis", "network analysis", and "implications analysis". Figure 1 summarizes our methodological approach.

Figure 1

Description of the systematic review of the database

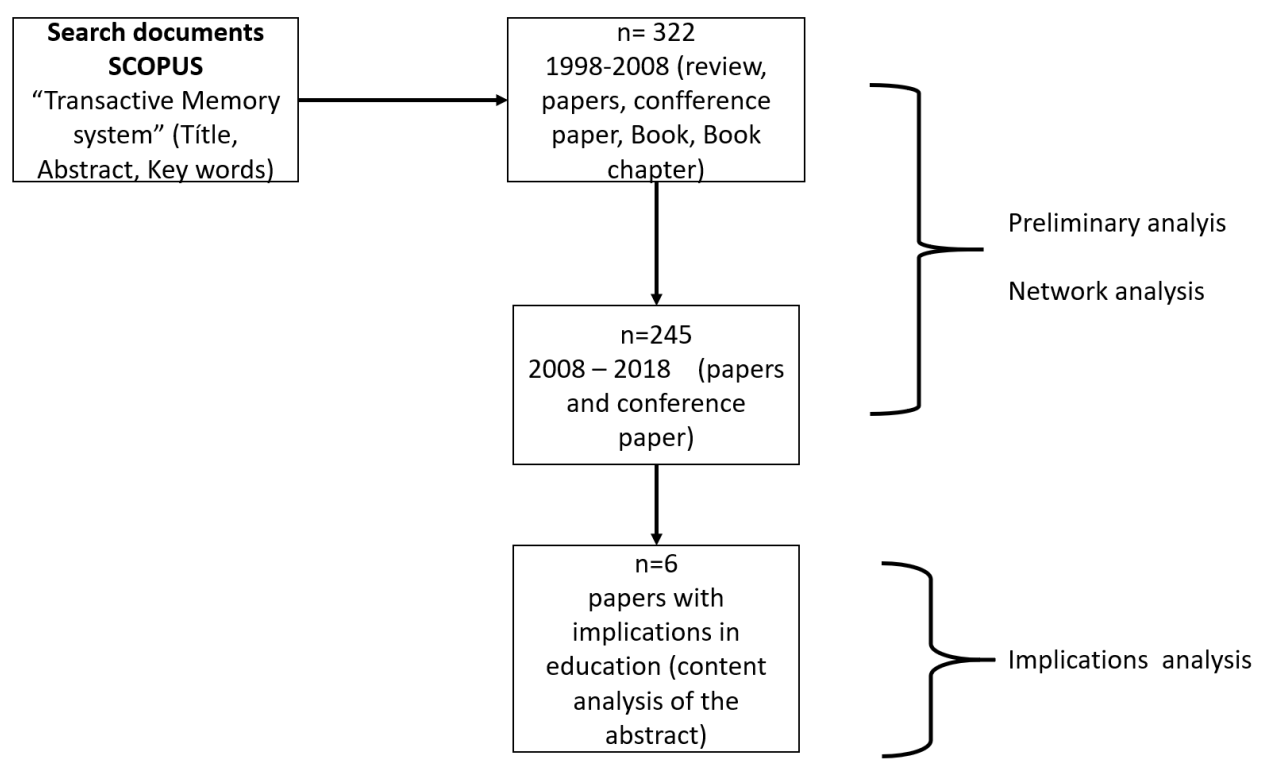

Source: Own elaboration 


\section{Results}

\subsection{Preliminary analysis}

Fig 2 shows the historical record of publications on TMS. We observed only five studies before 2000, and after this year it turned out to be evident a progressive increase in the publication of this topic. Between 1998 and 2008 we observed a total of 61 published papers. As of 2009, there was a substantial increase in the publication, as it reached 261 documents in the last ten years, revealing an increasing trend on TMS.

Figure 2

Historic record of publications on TMS

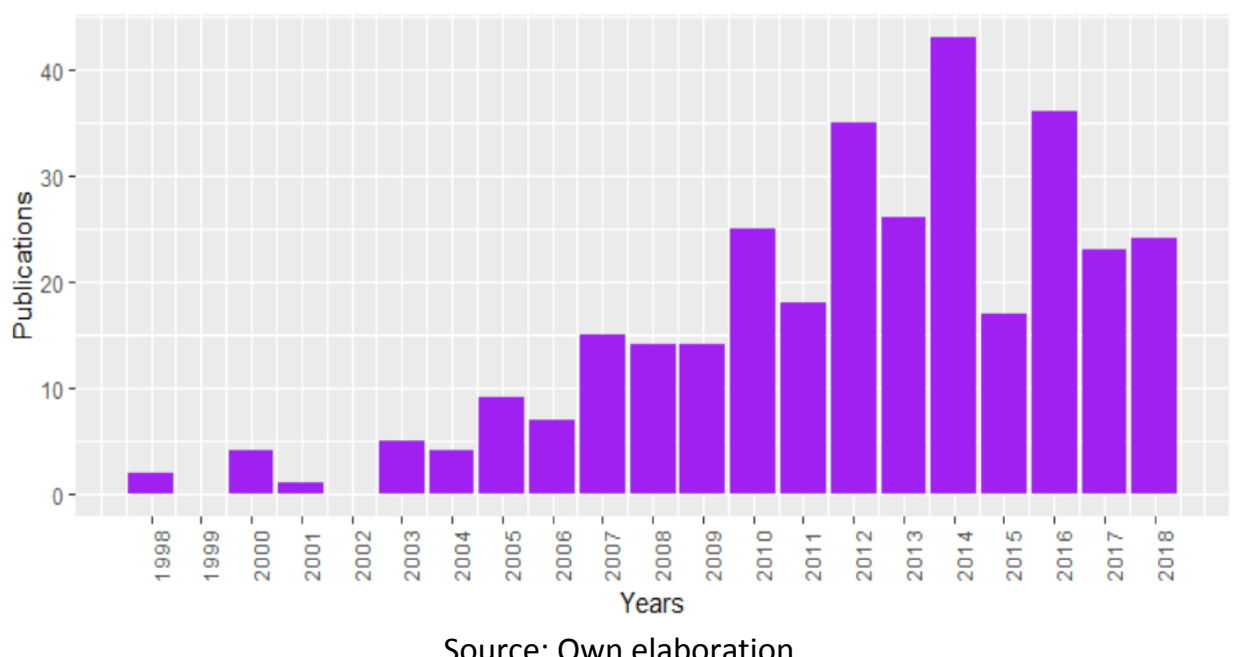

Source: Own elaboration

Fig 3 shows the distribution of papers according to the disciplines of the publishing journals. Almost half of the publications are concentrated in the disciplines of business and computer science. About a quarter of all documents are from the areas of social sciences and psychology, while the remaining percentage is scattered among decision sciences, engineering, arts and humanities, mathematics, economics, and medicine. Such a dispersion suggests that the research on TMS has been addressed in a multidisciplinary manner, being businessrelated disciplines those with more contributions to the field.

Figure 3

Distribution of publications on TMS by areas of knowledge

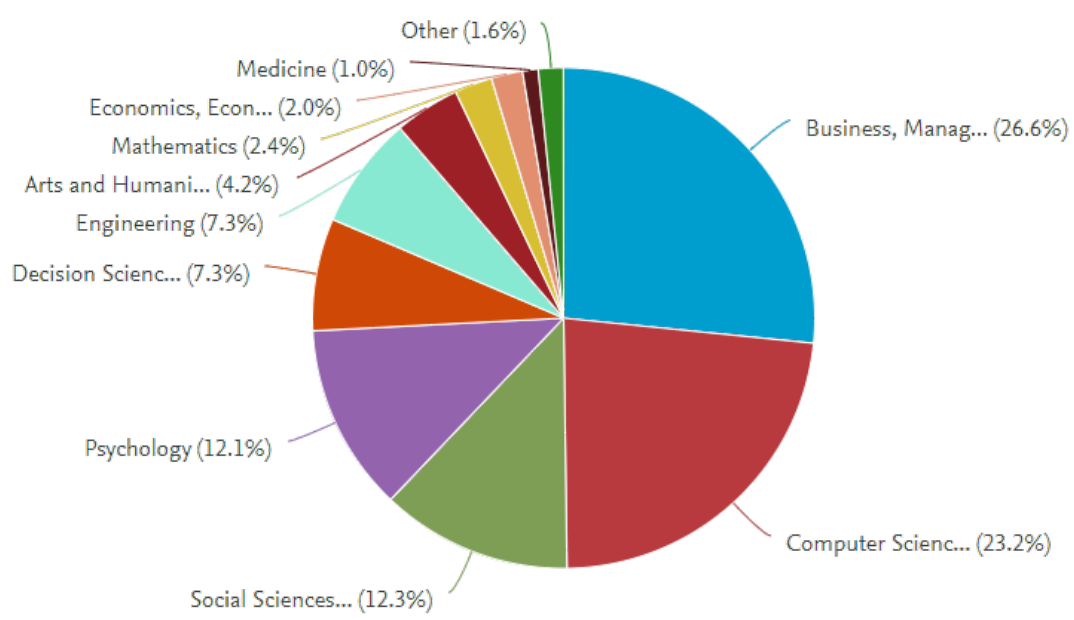

Source: Own elaboration 
Table 1 shows the top-20 of highly cited articles. The leading positions of this selective group of articles entail the psychometric measurement of TMS, including the differentiation among coordination, trust, and expertise as its three factors (Lewis 2003), the relationship between TMS and group performance (Austin 2003), the performance benefits of group training through TMS or improved group communication (Moreland and Myaskovsky 2000), a longitudinal study of TMS in knowledge-worker teams (Lewis 2004), and the role of knowledge coordination on virtual team performance (Kanawattanachai and Yoo 2007). From these set of papers, it can be easily understandable why the research on TMS has been mainly focused on the psychological basis of TMS and their possible applications to real-world contexts like the ones investigated by leading journals such as "Journal of Applied Psychology", "Management Information Systems", "Organizational Behavior and Human Decision Processes", "Management Science", "Organization Science", etc. The central literature has focused on the mechanisms by which TMS facilitates the group performance of workers, particularly emphasizing the role of coordination and expertise of the members of groups.

Table 1

Top-20 of highly cited articles

\begin{tabular}{|c|c|c|c|}
\hline Study & Title & Publication Source & Citations \\
\hline Lewis (2003) & $\begin{array}{l}\text { Measuring Transactive Memory Systems In The } \\
\text { Field: Scale Development And Validation }\end{array}$ & $\begin{array}{l}\text { Journal of Applied } \\
\text { Psychology }\end{array}$ & 470 \\
\hline Austin (2003) & $\begin{array}{l}\text { Transactive Memory In Organizational Groups: } \\
\text { The Effects Of Content, Consensus, Specialization, } \\
\text { And Accuracy On Group Performance }\end{array}$ & $\begin{array}{l}\text { Journal of Applied } \\
\text { Psychology }\end{array}$ & 353 \\
\hline $\begin{array}{l}\text { Moreland \& Myaskovsky } \\
(2000)\end{array}$ & $\begin{array}{l}\text { Exploring The Performance Benefits Of Group } \\
\text { Training: Transactive Memory Or Improved } \\
\text { Communication? }\end{array}$ & $\begin{array}{l}\text { Organizational } \\
\text { Behavior and } \\
\text { Human Decision } \\
\text { Processes }\end{array}$ & 349 \\
\hline Lewis (2004) & $\begin{array}{l}\text { Knowledge And Performance In Knowledge- } \\
\text { Worker Teams: A Longitudinal Study Of } \\
\text { Transactive Memory Systems }\end{array}$ & $\begin{array}{l}\text { Management } \\
\text { Science }\end{array}$ & 332 \\
\hline $\begin{array}{l}\text { Kanawattanachai \& Yoo } \\
\text { (2007) }\end{array}$ & $\begin{array}{l}\text { The Impact Of Knowledge Coordination On Virtual } \\
\text { Team Performance Over Time }\end{array}$ & $\begin{array}{l}\text { Mis Quarterly: } \\
\text { I Management } \\
\text { Information } \\
\text { Systems }\end{array}$ & 316 \\
\hline $\begin{array}{l}\text { Reagans, Argote, Brooks } \\
\text { (2005) }\end{array}$ & $\begin{array}{l}\text { Individual Experience And Experience Working } \\
\text { Together: Predicting Learning Rates From } \\
\text { Knowing Who Knows What And Knowing How To } \\
\text { Work Together }\end{array}$ & $\begin{array}{l}\text { Management } \\
\text { Science }\end{array}$ & 292 \\
\hline $\begin{array}{l}\text { Brandon \& Hollingshead } \\
\text { (2004) }\end{array}$ & $\begin{array}{l}\text { Transactive Memory Systems In Organizations: } \\
\text { Matching Tasks, Expertise, And People }\end{array}$ & $\begin{array}{l}\text { Organization } \\
\text { Science }\end{array}$ & 284 \\
\hline Hollingshead (1998) & $\begin{array}{l}\text { Communication, Learning, And Retrieval In } \\
\text { Transactive Memory Systems }\end{array}$ & $\begin{array}{l}\text { Journal of } \\
\text { Experimental } \\
\text { Social Psychology }\end{array}$ & 256 \\
\hline $\begin{array}{l}\text { Majchrzak, Jarvenpaa, } \\
\text { Hollingshead (2007) }\end{array}$ & $\begin{array}{l}\text { Coordinating Expertise Among Emergent Groups } \\
\text { Responding To Disasters }\end{array}$ & $\begin{array}{l}\text { Organization } \\
\text { Science }\end{array}$ & 248 \\
\hline Hollingshead (1998b) & $\begin{array}{l}\text { Retrieval Processes In Transactive Memory } \\
\text { Systems }\end{array}$ & $\begin{array}{l}\text { Journal of } \\
\text { Personality and } \\
\text { Social Psychology }\end{array}$ & 247 \\
\hline
\end{tabular}




\begin{tabular}{|c|c|c|c|}
\hline Study & Title & Publication Source & Citations \\
\hline $\begin{array}{l}\text { Young Choi, Lee \& Yoo } \\
\text { (2010) }\end{array}$ & $\begin{array}{l}\text { The impact of information technology and } \\
\text { transactive memory systems on knowledge } \\
\text { sharing, application, and team performance: a } \\
\text { field study }\end{array}$ & $\begin{array}{l}\text { Mis Quarterly: } \\
\text { Management } \\
\text { Information } \\
\text { Systems }\end{array}$ & 235 \\
\hline Lewis, Lange \& Gillis (2005) & $\begin{array}{l}\text { Transactive memory systems, learning, and } \\
\text { learning transfer }\end{array}$ & $\begin{array}{l}\text { Organization } \\
\text { Science }\end{array}$ & 213 \\
\hline $\begin{array}{l}\text { Akgün, Byrne, Keskin, Lynn } \\
\text { \& Imamoglu (2005) }\end{array}$ & $\begin{array}{l}\text { Knowledge networks in new product } \\
\text { development projects: a transactive memory } \\
\text { perspective }\end{array}$ & $\begin{array}{l}\text { Information and } \\
\text { Management }\end{array}$ & 192 \\
\hline Ren \& Argote (2011) & $\begin{array}{l}\text { Transactive memory systems 1985-2010: an } \\
\text { integrative framework of key dimensions, } \\
\text { antecedents, and consequences }\end{array}$ & $\begin{array}{l}\text { Academy of } \\
\text { Management } \\
\text { Annals }\end{array}$ & 168 \\
\hline $\begin{array}{l}\text { Lewis, Belliveau, Herndon \& } \\
\text { Keller (2007) }\end{array}$ & $\begin{array}{l}\text { Group cognition, membership change, and } \\
\text { performance: investigating the benefits and } \\
\text { detriments of collective knowledge }\end{array}$ & $\begin{array}{l}\text { Organizational } \\
\text { Behavior and } \\
\text { Human Decision } \\
\text { Processes }\end{array}$ & 155 \\
\hline $\begin{array}{l}\text { Zhang, Hempel, Han \& } \\
\text { Tjosvold (2007) }\end{array}$ & $\begin{array}{l}\text { Transactive memory system links work team } \\
\text { characteristics and performance }\end{array}$ & $\begin{array}{l}\text { Journal of Applied } \\
\text { Psychology }\end{array}$ & 137 \\
\hline Lewis \& Herndon (2011) & $\begin{array}{l}\text { Transactive memory systems: current issues and } \\
\text { future research directions }\end{array}$ & $\begin{array}{l}\text { Organization } \\
\text { Science }\end{array}$ & 132 \\
\hline $\begin{array}{l}\text { Rosen, Furst \& Blackburn } \\
\text { (2007) }\end{array}$ & $\begin{array}{l}\text { Overcoming barriers to knowledge sharing in } \\
\text { virtual teams }\end{array}$ & $\begin{array}{l}\text { Organizational } \\
\text { Dynamics }\end{array}$ & 130 \\
\hline Nevo \& Wand (2005) & $\begin{array}{l}\text { Organizational memory information systems: a } \\
\text { transactive memory approach }\end{array}$ & $\begin{array}{l}\text { Decision Support } \\
\text { Systems }\end{array}$ & 130 \\
\hline $\begin{array}{l}\text { Jarvenpaa \& Majchrzak } \\
\text { (2008) }\end{array}$ & $\begin{array}{l}\text { Knowledge collaboration among professionals } \\
\text { protecting national security: role of transactive } \\
\text { memories in ego-centered knowledge networks }\end{array}$ & $\begin{array}{l}\text { Organization } \\
\text { Science }\end{array}$ & 119 \\
\hline
\end{tabular}

\subsection{Network Analysis}

Fig 4 shows a cited reference network. In this network, four documents do not belong to the corpus of the original 322 publications, as they were not indexed in the Scopus database, but proved to be seminal for the theoretical development of TMS: "Transactive Memory: A Contemporary Analysis of the Group Mind" (Wegner 1987), "A computer network model of human transactional memory" (Wegner 1995), "Transactive memory in close relationships" (Wegner et al. 1991) and "Cognitive interdependence in close relationships" (Wegner et al., 1985). The papers presented in Table 1 also appeared in this cited reference network. 
Figure 4

Network of direct citations among a sample of representative published articles on TMS between 1998 and 2018

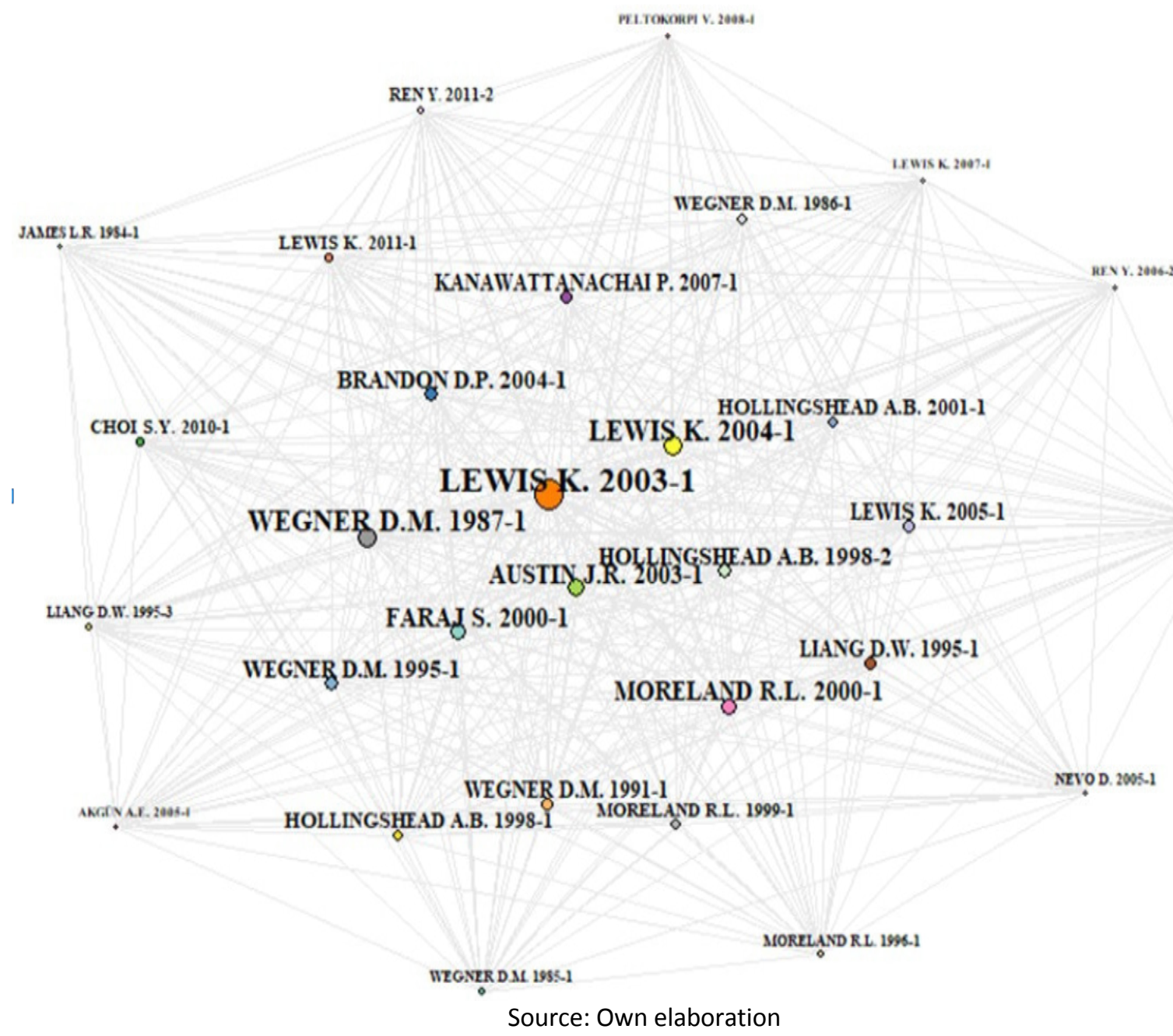

The keyword co-occurrence network of the representative published articles on TMS is depicted in Fig 5 . This network shows a total of 1,937 connections between a total of 580 terms that appeared as keywords in the set of the 322 published articles on TMS. The words with the highest number of links were "transactive memory systems" (461) and "transactive memory" (132), and "team performance" (67). The average degree for the terms of this network was 6.827 which means that each node connects directly with other seven nodes. The network diameter was 6 , which can be understood as the minimum number of terms that any researcher should use to find relevant papers on TMS in the Scopus database. The graph density, however, proved to be 0.012 , which means that only $1.2 \%$ of its nodes are connected in comparison with the maximum possible number of connections between pair of nodes. 
Figura 5

Keyword co-occurrence network from a sample of representative published articles on TMS

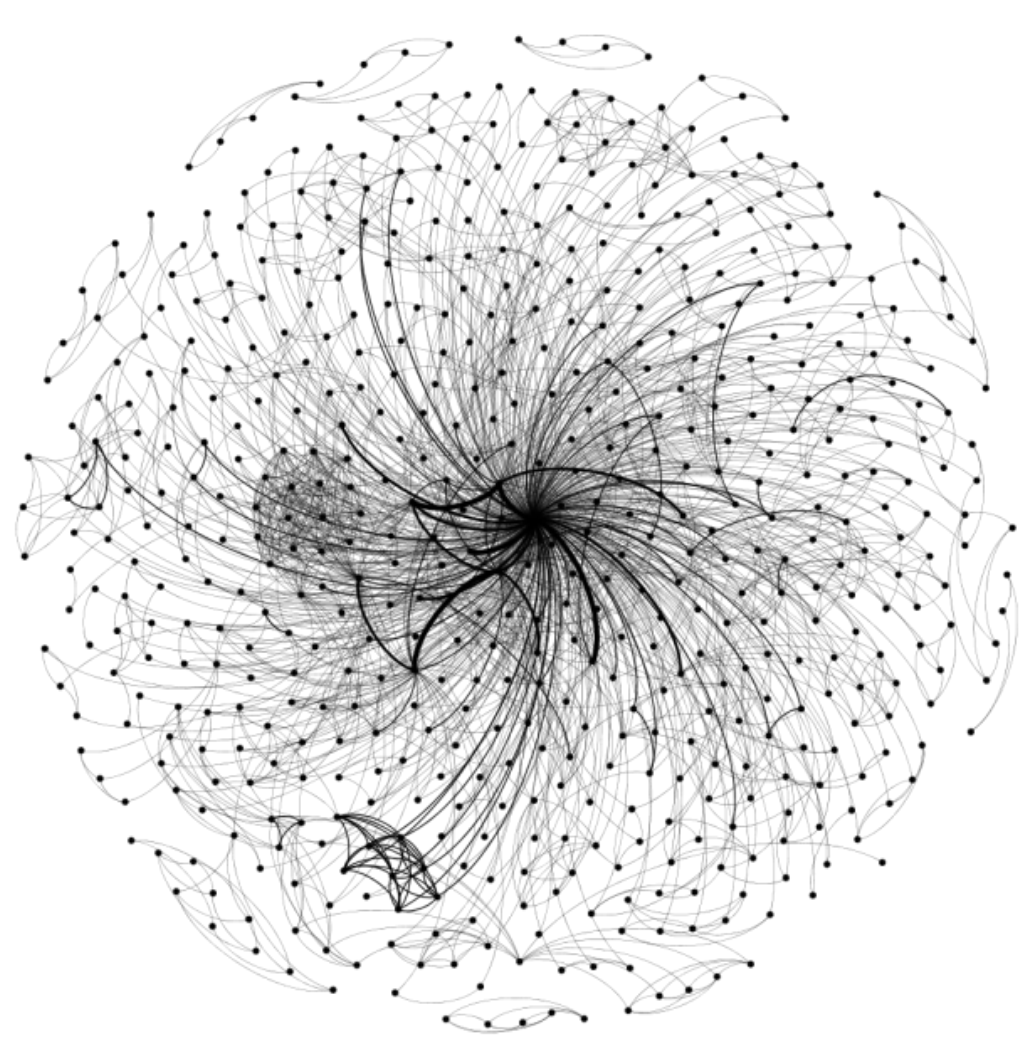

Source: Own elaboration

From the above network, we found 19 semantically relevant terms that are commonly related to education, teaching, and learning. This number represents that only $3.275 \%$ of the nodes in the graph are of the interest of an educational researcher. The semantic proximity of these terms with TMS was estimated via "degree centrality" (i.e., the number of other nodes linked to each term), "eccentricity" (i.e., the distance of the term to its most distant node) and "closeness centrality" (i.e., the proximity of each term to all other nodes within the graph).

Table 2

Graph statistics of commonly related terms to education, teaching, and learning

\begin{tabular}{lccc}
\hline Terms & Degree centrality & Eccentricity & Closeness centrality \\
\hline Team learning & 17 & 4 & 0.483 \\
\hline Organizational learning & 17 & 4 & 0.451 \\
\hline Group learning & 12 & 4 & 0.476 \\
\hline Collective learning & 10 & 0.442 \\
\hline Learning effort & 8 & 0.436 \\
\hline Computer-supported collaborative learning & 4 & 0.441 \\
\hline Learning curves & 7 & 4 & 0.436 \\
\hline
\end{tabular}




\begin{tabular}{lccc}
\hline Terms & Degree centrality & Eccentricity & Closeness centrality \\
\hline Learning & 5 & 4 & 0.436 \\
\hline Continuing interprofessional education & 5 & 4 & 0.434 \\
\hline Exploitative learning & 4 & 4 & 0.434 \\
\hline Exploratory learning & 4 & 4 & 0.434 \\
\hline Online learning & 3 & 4 & 1 \\
\hline Innovative teaching approach & 3 & 4 & 0.433 \\
\hline Learning satisfaction & 3 & 4 & 0.434 \\
\hline Peer learning & 3 & 4 & 0.434 \\
\hline Organizational learning and change & 3 & 4 & 0.434 \\
\hline Team learning activities & 3 & 4 & 0.434 \\
\hline Software engineering education & 2 & 4 & 0.433 \\
\hline Learning organizations & 2 & 439 \\
\hline
\end{tabular}

Source: Own elaboration. Calibri

\subsection{Implication Analysis}

In the past Jackson and Moreland (2009) suggested three possible directions for future research: 1) the value of evaluating the effects of teaching styles on TMS, 2) estimating the effect of turnover in groups on TMS, and 3) the evaluation of changes in TMS when competition between groups is introduced. Beyong these suggestions, we believe that the concept of transactive memory system posits the following implications for higher education settings. In the first place, as TMS takes some time before the members of a group can develop it, the educator plays a fundamental role in structuring educational tasks that stimulate collaboration among students. Educators, in this way, might be benefited from knowing the dimensions of TMS (i.e., expertise, trust, and coordination) and how to promote them in the classroom (Jackson and Moreland 2009). As university students are not necessarily aware of these dimensions and their roles on group performance, students will easily recognize the relevance of collaboration when it comes to learning and contributing to others' efforts for achieving a common goal (Zhang et al. 2016). In situations of this sort, educators should emphasize that the collaborative tasks that are conducted in the classroom might be deemed as preliminary experiences for future labor experiences. These ideas might demand the development of teacher training processes aimed at optimizing teaching based on collaborative learning and teamwork (Mo and Xie 2010). As the collaboration of university students should be structured, accompanied and guided by educators aware of the implications of TMS (Kreijns et al. 2003), it becomes evident the need to popularize these implications.

Another implication is that educators might act as monitors that help students in recognizing the expertise of peers so they can reach the principle of who knows what and apply it for future situations where success is highly dependent on the ability to recognize each member's expertise, to optimize the work of the group (Nisiotis et al. 2017). When a student recognizes the expertise of others, this implies that the professor in the classroom is not anymore the only credible source of knowledge to follow, and this might help to increase the confidence a group needs to succeed. As an example, think in the case of an introductory course of research skills, where students 
are asked to form a group of three to prepare the draft of a scientific project. In this case, students know that they need to develop information search skills that allow them to find relevant literature, along with skills of critical reading, and writing. In this case, efficient preparation of the draft implies the division of the task into three subtasks: literature search, literature comprehension, and writing a review of the literature. Here, the professor might ask the students to decide who will be the responsible for the information search and why, who will be in charge of conducting the critical reading, and who will write the draft of the scientific project.

The principle of who knows what and the dimensions of TMS are critical for both traditional and online higher education settings (Noroozi et al. 2013). Nonetheless, each modality demands a different implementation. While the educator plays an essential role in structuring educational tasks that promote collaboration among students in both traditional and virtual education, computer-supported collaborative learning tools are vital (Yilmaz et al. 2016; Yilmaz et al., 2019) for monitoring the interaction between student when they need to work on a common task in virtual programs (Collazos et al. 2002; Collazos et al. 2007). These tools should be developed and implemented to facilitate the task of tracking the development of TMS in a group.

\section{Conclusions}

The bibliographic description of the research on TMS to reveal its implications for higher education settings was the aim of this work. Our results have shown that the literature that connects the principles of TMS to higher education is in its early stage. Nonetheless, the relevance of this topic emerges when we concur with the idea posited by Yilmaz et al., (2019) that collaborative learning is regarded as an essential skill for 21st-century learners, because it implies that the group members construct the knowledge while learners are working together for a common goal. As a cognitive property of a group of students, TMS facilitates the individual awareness of who knows what (Moreland 2015), and this posits the possibility for the students of learning from credible sources of information other than the educator in the classroom. If educators promote this idea in their students, then teaching-learning practices will impact the way we have considered the assessing of quality and evaluation of performance in higher education (Sarrico et al. 2010). For instance, Taglieri (2010) has emphasized that as group collaboration is becoming vital in the workplace, undergraduate curriculums must be updated to include group project courses that help to prepare students for their post- graduation work.

More empirical research is certainly needed to reveal the ways in which TMS could benefit students' learning efforts and educators' teaching practices in institutions of higher education. The fact that the most recent works on TMS are getting published in journals that do not belong to the education field leads us to pinpoint a unique opportunity for educators. This opportunity consists of getting involved in interdisciplinary groups that investigate the value added that graduate students might have if they are trained in collaboration tasks from its first years of university education.

\section{Bibliographic References}

Akgün, Ali E., John Byrne, Halit Keskin, Gary S. Lynn, and Salih Z. Imamoglu. (2005). Knowledge networks in new product development projects: A transactive memory perspective. Information \& Management 42: 11051120. doi:10.1016/j.im.2005.01.001.

Aria, Massimo, and Corrado Cuccurullo. (2017). bibliometrix : An R-tool for comprehensive science mapping analysis. In Journal of Informetrics, 11:959-975. Elsevier Ltd. doi:10.1016/j.joi.2017.08.007.

Austin, John R. (2003). Transactive memory in organizational groups: The effects of content, consensus, specialization, and accuracy on group performance. Journal of Applied Psychology 88: 866-878. doi:10.1037/0021-9010.88.5.866. 
Brandon, D \& Hollingshead, A B. (2004). Transactive Memory Systems in Organizations: Matching Tasks, Expertise, and People. Organization Science 15: 644-644. doi:10.1287/orsc.

Cherven, Ken. (2015). Mastering Gephi Network Visualization. 1st ed. Birmingham, UK: Packt Publishing Ltd.

Choi, Sue Young, Heeseok Lee, and Youngjin Yoo. (2010). The impact of information technology and transactive memory systems on knowledge sharing, application, and team performance: a field study. MIS QUARTERLY 34: 855-870.

Collazos, C., L. Guerrero, J. Pino, S. Renzi, Jane Klobas, M. Ortega, M. Redondo, and C. Bravo. (2007). Evaluating collaborative learning processes using system-based measurement. Educational Technology and Society 10: 257-274. doi:10.1126/science.1168450.

Collazos, C, L Guerrero, J Pino, and S Ochoa. (2002). Evaluating collaborative learning processes. Groupware: Design, Implementation, and Use 2440: 173-194. doi:10.1007/3-540-46124-8_14.

Hollingshead, A. (1998). Retrieval Processes in Transactive Memory Systems. Journal of Personality and Social Psychology 74: 659-671.

Hollingshead, A. (2001). Cognitive interdependence and convergent expectations in transactive memory. Journal of personality and social psychology 81: 1080-1089. doi:10.1037/0022-3514.81.6.1080.

Hollingshead, A., N. Gupta, K. Yoon, and D. P. Brandon. (2012). Transactive memory theory and teams: Past, present, and future. In Theories of team cognition: Cross-disciplinary perspectives, 421-456.

Hollingshead, Andrea. (1998). Communication, Learning, and Retrieval in Transactive Memory Systems. Journal of Experimental Social Psychology 34: 423-442.

linuma, Mizuho, Takashi Matsuhashi, Tagiru Nakamura, and Hiroaki Chiyokura. (2016). Student Awareness Change in Computer Supported Collaborative Learning (CSCL) Environment. International Journal of Information and Education Technology 6: 448-452. doi:10.7763/IJIET.2016.V6.730.

Jackson, M, and Richard L Moreland. (2009). Transactive Memory in the Classroom. Small Group Research 40: 508-534. doi:10.1177/1046496409340703.

Jarvenpaa, Sirkka L., and Ann Majchrzak. (2008). Knowledge Collaboration Among Professionals Protecting National Security: Role of Transactive Memories in Ego-Centered Knowledge Networks. Organization Science 19: 260-276. doi:10.1287/orsc.1070.0315.

Jhonson, D., Jhonson, R., Holubec, E. (1994). Cooperative learning in he classroom. 15th ed. Alexandria, VA 22314.

Kanawattanachai, $P$, and $Y$ Yoo. (2007). The impact of knowledge coordination on virtual team performance over time. MIS Quarterly: Management Information Systems 31: 783-808.

Kreijns, Karel, Paul A. Kirschner, and Wim Jochems. (2003). Identifying the pitfalls for social interaction in computer-supported collaborative learning environments: A review of the research. Computers in Human Behavior 19: 335-353. doi:10.1016/S0747-5632(02)00057-2.

Kroeger, Paul. (2005). Analyzing Grammar: An Introduction. 1st ed. New York, United States of America: Cambridge University Press.

Lewis, Kyle. (2003). Measuring transactive memory systems in the field: scale development and validation. Journal of Applied Psychology 88: 587-604. doi:10.1037/0021-9010.88.4.587.

Lewis, Kyle. (2004). Knowledge and Performance in Knowledge-Worker Teams : A Longitudinal Study of Transactive Memory Systems Knowledge and Performance in Knowledge-Worker Teams : A Longitudinal 
Study of Transactive Memory Systems. Management Science 50: 1519-1533.

doi:10.1287/mnsc.1040.0257.

Lewis, Kyle, Maura Belliveau, Benjamin Herndon, and Joshua Keller. (2007). Group cognition, membership change, and performance: Investigating the benefits and detriments of collective knowledge.

Organizational Behavior and Human Decision Processes 103: 159-178. doi:10.1016/j.obhdp.2007.01.005.

Lewis, Kyle, and Benjamin Herndon. (2011). Transactive Memory Systems: Current Issues and Future Research Directions. Organization Science 22: 1254-1265. doi:10.1287/orsc.1050.0136.

Lewis, Kyle, Donald Lange, and Lynette Gillis. (2005). Transactive Memory Systems, Learning, and Learning Transfer. Organization Science 16: 581-598. doi:10.1287/orsc.1050.0143.

Liang, Diane Wei, Richard Moreland, and Linda Argote. (1995). Group Versus Individual Training and Group Performance: The Mediating Role of Transactive Memory. Journal of Composite Materials 21: 384-393. doi:0803973233.

Majchrzak, Ann, Sirkka L. Jarvenpaa, and Andrea B. Hollingshead. (2007). Coordinating Expertise Among Emergent Groups Responding to Disasters. Organization Science 18: 147-161. doi:10.1287/orsc.1060.0228.

Miller, Mariel, and Allyson Hadwin. (2015). Scripting and awareness tools for regulating collaborative learning: Changing the landscape of support in CSCL. Computers in Human Behavior 52. Elsevier Ltd: 573-588. doi:10.1016/j.chb.2015.01.050.

Mo, S, and X Xie. (2010). Team learning, transactive memory system and team performance: A longitudinal study based on the IMOI approach. Frontiers of Business Research in China 4: 409-422. doi:10.1007/s11782-010-0104-1.

Moreland, Richard L. (2015). Transactive Memory: Learning Who Knows What in Work Groups and Organizations. In Small Groups, ed. J. M. Levine and Richard L. Moreland. Vol. 1. New York: Psychology Press.

Moreland, Richard L., Linda Argote, and Ranjani Krishnan. (1996). Socially Shared Cognition at Work: Transactive Memory and Group Performance. In What's Social about Social Cognition? Research on Socially Shared Cognition in Small Groups, ed. J. L. \&. Nye and A.M. Brower, 57-84. Thousand Oaks, California: Sage. doi:10.4135/9781483327648.n3.

Moreland, Richard L., and Larissa Myaskovsky. (2000). Exploring the Performance Benefits of Group Training: Transactive Memory or Improved Communication? Organizational Behavior and Human Decision Processes 82: 117-133. doi:10.1006/obhd.2000.2891.

Nevo, D, and Y Wand. (2005). Organizational memory information systems: a transactive memory approach. Decision Support Systems 39: 549-562. doi:10.1016/j.dss.2004.03.002.

Nisiotis, Louis, Styliani Kleanthous, Martin Beer, and Elizabeth Uruchurtu. (2017). The Development of Transactive Memory Systems in Collaborative Educational Virtual Worlds. In Immersive Learning Research Network. Third International Conference, iLRN 2017, ed. Dennis Beck, Colin Allison, Leonel Morgado, Johanna Pirker, Foaad Khosmood, Jonathon Richter, and Christian Gütl, 35-46. Coimbra, Portugal: Springer. doi:10.1007/978-3-319-41769-1.

Noroozi, Omid, Harm J A Biemans, Armin Weinberger, Martin Mulder, and Mohammad Chizari. (2013). Scripting for construction of a transactive memory system in multidisciplinary CSCL environments. Learning and Instruction 25. Elsevier Ltd: 1-12. doi:10.1016/j.learninstruc.2012.10.002. 
Peltokorpi, V. (2008). Transactive Memory Systems. Review of General Psychology 12: 378-394. doi:10.1037/1089-2680.12.4.378.

R Core Team. 2019. R: A language and environment for statistical computing. Vienna, Austria: R Foundation for Statistical Computing.

Reagans, Ray, Linda Argote, and Daria Brooks. (2005). Individual Experience and Experience Working Together: Predicting Learning Rates from Knowing Who Knows What and Knowing How to Work Together. Management Science 51: 869-881. doi:10.1287/mnsc.1050.0366.

Ren, Y, and L Argote. (2011). Transactive memory systems 1985-2010: An integrative framework of key dimensions, antecedents, and consequences. Academy of Management Annals 5: 189-229. doi:10.1080/19416520.2011.590300.

Rosen, B., S. Furst, and R. Blackburn. (2007). Overcoming Barriers to Knowledge Sharing in Virtual Teams. Organizational Dynamics 36: 259-273. doi:10.1016/j.orgdyn.2007.04.007.

Sarrico, Cláudia S., Maria J. Rosa, Pedro N. Teixeira, and Margarida F. Cardoso. (2010). Assessing quality and evaluating performance in higher education: Worlds apart or complementary views? Minerva 48: 35-54. doi:10.1007/s11024-010-9142-2.

Taglieri, By Lauren. (2010). Transactive Memory Systems in Undergraduate Information Systems Student Project Groups. Carnegie Mellon University.

Wegner, Giuliano \& Hertel, P. (1985). Cognitive interdependence in close relationships. In Compatible and incompatible relationships, 253-276. New York: Springer-Verlag. doi:10.1007/978-1-4612-5044-9_12.

Wegner, D. (1987). Transactive Memory: A Contemporary Analysis of the Group Mind. In Theories of Group Behavior, ed. Brian Mullen and George R. Goethals, 185-208. New York: Springer. doi:10.1007/978-14612-4634-3_9.

Wegner, D. (1995). A computer network model of human transactive memory. Journal of Chemical Information and Modeling 13: 319-339. doi:10.1017/СВ09781107415324.004.

Wegner, D, R Erber, and P Raymond. (1991). Transactive memory in close relationships. Journal of personality and social psychology 61: 923-929. doi:10.1037/0022-3514.61.6.923.

Yilmaz, Fatma Gizem Karaoglam, and Ramazan Yilmaz. (2019). Impact of pedagogic agent-mediated metacognitive support towards increasing task and group awareness in CSCL. Computers \& Education. doi:10.1016/j.compedu.2019.02.001.

Yilmaz, Ramazan, Fatma Gizem, Karaoglan Yilmaz, and Ebru Kilic Cakmak. (2016). The impact of transactive memory system and interaction platform in collaborative knowledge construction on social presence and self- regulation. Interactive Learning Environments 4820. Taylor \& Francis: 1-21. doi:10.1080/10494820.2016.1224905.

Zhang, X., H. Chen, P. O. de Pablos, M. D. Lytras, and Y. Sun. (2016). Coordinated implicitly? An empirical study on the role of social media in collaborative learning. International Review of Research in Open and Distance Learning 17: 121-144.

Zhang, Zhi-Xue, Paul S Hempel, Yu-Lan Han, and Dean Tjosvold. (2007). Transactive memory system links work team characteristics and performance. Journal of Applied Psychology 92: 1722-1730. doi:10.1037/00219010.92.6.1722.

Esta obra está bajo una Licencia Creative Commons Attribución-NoCommercial 4.0 International 